\title{
A MAGYAR FEJLESZTÉSI POLITIKA TÉRSZEMLÉLETE ÉS A MÁSODIK GENERÁCIÓS PROGRAMOZÁS TERÜLETI VETÜLETEI
}

\author{
(Views on Space in Hungarian Development Policy and \\ the Spatial Aspects of Second Generational Programming) \\ LUX GÁBOR
}

Kulcsszavak:

terilletfejlesztés decentralizáció második generációs programozás

A tanulmány áttekinti a magyar területfejlesztés térszemléletének változásait, és összeveti ezt a gazdaságban végbemenõ reálfolyamatok alakulásával. A magyar területfejlesztés eszmei-politikai gyökerei a szocialista területi tervezés részleges kritikájából erednek, és a rendszerváltás után bekövetkezett recentralizáció a mai fejlesztési dokumentumokban is érezteti hatását. A második generációs programozásnak egyaránt föl kell készuilnie az EU teriuletfejlesztési reformjára és a globalizáció támasztotta kihivások kezelésére. Ezért nem halogathatók tovább a terilleti reformok, de ezek megvalósitása csak a hatékonyság és a demokratikus szempontok következetes megvalósitásával lehet sikeres.

\section{Alapgondolatok}

Hazánk 2004-es EU-csatlakozását követően nálunk is beindultak a régi tagállamokra már jellemző nemzeti fejlesztési rendszerek, amelyek elsősorban a közösségi források felhasználására, másodsorban a hazai fejlesztési elképzelések megvalósítására irányulnak. Ez a helyzet több tekintetben sajátos, és várhatóan az elkövetkező években is az marad:

- Brüsszelböl nézve Magyarország területi különbségei sokkal kevésbé látványosak, és a központi régió kivételével az egész országterület belemosódik az EU keleti perifériáját képező, a III. Kohéziós Jelentésben látványosan vörössel jelölt „vörös sarlóba”. Ezért a fejlesztési irányok kijelölése relatíve tág mozgásteret ad a hazai döntéshozók számára.

- A magyar régió - fikció. A regionális szint kijelölése a magyar történelemben általában oktrojált reformok terméke volt; a közigazgatás és a helyi identitás alapját a megyék képezték. Nem alakult ki szerves régió; 1990 utáni megjelenése ismét külső mintára vezethető vissza. Ebböl nem következik, hogy ne is legyen, de be kell látnunk, hogy kialakítása, lehatárolása és milyensége (tartalommal való felruházása) a magyar állam és az EU közremúködésével lezajló döntési folyamat terméke lesz.

- A 2004-2006-os uniós programozási időszakba Magyarország késve kapcsolódott be, ezért a létrejött megoldások felemásak, ideiglenesek. A kỏvetkező programozási időszakra való felkészülés során már levonhatunk következte- 
téseket a mechanizmus mai múködéséböl, de a közösségi politika irányváltozásait is anticipálnunk kell. Az Európai Területfejlesztési Perspektíva (European Spatial Development Perspective, ESDP), a III. Kohéziós Jelentés, majd az EU 2007 és 2013 közötti stratégiai irányelveit összefoglaló Kohéziós Politika a Növekedés és a Foglalkoztatás Érdekében (Cohesion Policy in Support of Growth and Jobs) több ponton radikálisan szakítanak az érvényes uniós elvekkel: beismerik az eddigi intézkedések részleges kudarcát, és a gazdasági növekedés fokozásában jelölik meg a közeljövő fö feladatát.

- A jelenleg meghozott döntések mintegy hét évre elörevetítik fejlỏdési pályánkat, mivel a 2006-ban létrejövő és az Unióval egyeztetett tervdokumentumok 2013-ig érvényesek. A magyar választási rendszerben ez azt jelenti, hogy a következö kormány (2006-2010) pártállásától és összetételétől függetlenül egy elöre kialakított szisztéma ,foglya" lesz; sőt, utódja is csak a legutolsó évét tölti majd a rákövetkezö időszakban. Ez a hosszútávú szemlélet mindeddig idegen volt a magyar gazdaságpolitikától; és fokozott felelősséggel, demiurgoszi erőkkel ruházza föl a mai döntéshozókat.

A magyar területi és fejlesztési tervezés tehát most alakítja ki jövőbeli mozgásterét és annak határait. Felelössége azért is nagy, mert nem áll mögötte erös társadalmi kontroll. A megvalósuló konfigurációt egy pozitivista szakmai-tudományos elit normatív elképzeléseinek figyelembevételével a politika szentesíti. Azaz - szem elött tartva a még relatíve tiszta tervezőasztal adta lehetőségeket - egyaránt kockázati tényezỏ a partikuláris érdekek lopakodó beépítése és a megvallott-megvallatlan tervezöi szimpátiák korlátlan érvényesülése (Faragó 2000). Ugyanakkor pont a társadalmi participáció gyengeségéből adódóan nem is tisztességes a közakaratra hivatkozni és a posztmodern „virágozzék száz virág” jegyében olyan elképzeléseket megvalósítani, amelyek mögött semmiféle garancia, még a tudományos közvélemény vagy a választott képviselői státusz sok tekintetben megkérdőjelezhetö legitimitása sem áll.

Ebben a tanulmányban nem vállalkozunk az eljövendő változások széleskörủ körüljárására, hanem csupán arra keressük a választ, hogy milyen reálfolyamatokon és eszmei alapokon nyugszik a magyar területfejlesztési politika, ez hogyan csapódik le a nemzeti fejlesztéspolitikát dokumentumokban rögzítő második generációs programozás rendszerében, és milyen válaszokat adhat a politika a magyar térszervezés kihívásaira. Elöre kell bocsátanunk, hogy a tanulmány a programozási időszak során, munkaanyagok fölhasználásával készült. Ezt az irodalomjegyzékben is megjelöltiik.

\section{A magyar térszerkezetet alakító folyamatok}

Az elözőekben hangsúlyoztuk, hogy a tervezés jelentös mozgástérrel rendelkezik. A döntések azonban egy adott tér keretei között valósulnak meg, s figyelembe kell venniük az eddig lezajlott és ma is zajló folyamatok eredményeit, választ adva arra is, hogy a létező trendek folytatódása vagy azok (sokkal erőforrás-igényesebb) elterelése, megtörése kívánatos a közjó számára. A szerzö véleménye szerint a 
magyar területfejlesztés mozgásterét alakító három legfontosabb tényező a szocialista örökség és annak 1989 utáni kritikája, a gazdasági-politikai orientációváltás következményei és harmadikként az uniós integráció által támasztott követelményeknek való megfelelés igénye.

\section{A szocializmus terïleti hatásai}

Az 1948-49-től 1989-ig uralkodó szocialista ideológia már önmagában több ellentmondást hordozott. Deklarációiban a párt a területi különbségek megszüntetését hirdette, és tagadta a helyi „másság” létezését. Az uralkodó egalitárius eszme a maga torz megvalósulásában is tartalmi változást jelentett a korábbi duális területi szerkezet megosztottságához képest (Beluszky 2003). Másrészt a gyakorlatban igen erös diszkrimináció érvényesült mind a közigazgatási beosztás, mind az országon belüli elhelyezkedés mentén. A területi differenciálódás két meghatározó eszköze a közigazgatási politika és az iparpolitika volt, amit harmadikként a biztonságpolitika egészített ki.

A közigazgatási politika ideológiai alapját kijelölö, pozitivista hagyományokból táplálkozó gazdaságföldrajz a gazdasági tér objektivitásából (a terïleti munkamegosztásból és a vonzáskörzetek kisugárzó hatásából) vezette le a térszervezés kívánatos rendszerét (Horváth 1989; Beluszky 2002). Radikális területi reformra politikai okokból nem került sor, ehelyett a meglévő közigazgatási struktúrát formálták át és ruházták föl új tartalommal (Hajdú 2001). Kezdetben minden addiginál erösebb hatalmi koncentráció ment végbe a fövárosban. Ez hozzávetőlegesen 1948-tól 1965-ig tartott és az egész országot Budapest perifériájaként kezelte (Beluszky 2000). A központi irányítás oldódásával megerősödhettek a megyeszékhelyek és az 1971-ben érvénybe lépett Országos Településhálózat-fejlesztési Koncepció nómenklatúrája lényegében világosan kijelölte a fejlódés kereteit: az egész országra érvényes elvek alapján a településhierarchiában elfoglalt hely határozta meg a települések fejlődési lehetőségeit. Fokozatosan erősödött a vonzáskörzeti szemlélet befolyása, miközben megmaradt az urbanizáció és a fejlődés közötti egyenlöségtétel.

A közigazgatási politika hatását mindvégig eltérítette a szocialista korszak ideológiai kulcstényezője, az iparpolitika. Az iparpolitikát „primus inter pares” státusza az ágazati politikák között és a szovjet hatalmi érdekek olyan erövé tették, amely párhuzamos müködésével figyelmen kívül hagyhatta a közigazgatási beosztás kényszerítő erejét; csak a nyolcvanas években eshetett szó túlméretezettségéröl és ennek árnyoldalairól (Winiecki 1986). Az iparpolitika logikájảt a német gyökerü, de szovjet közvetítéssel behozott telephelyelmélet kormányozta. Az ipart a nyersanyagok, elsősorban az energiabázis 80\%-át adó kőszén lelőhelyei mellé telepítették, és ezen az alapon iparvidékeket, új városokat hoztak létre vagy fejlesztettek ki korábbi településekböl (Barta 2002)1 I Így alakult ki a kelet-nyugat választóvonal helyett az úgynevezett „energiatengely”, amely északkelet-délnyugati irányban átszelte az országot és kedvezményezett térségeiben egy erősen iparosodott zónát hozott létre. 
Mind az iparpolitika, mind a közigazgatási politika mozgásterét behatárolta a biztonságpolitika szempontrendszere. Megszállt országként Magyarország területfejlesztési döntéseit bármikor fölülírhatta a szovjet parancs. Már Sztálinváros helyének kiválasztásakor is meghatározó súllyal esett a latba, hogy az eleinte az északi iparvidékek ellenpólusaként elképzelt Mohács túl közel esett Tito Jugoszláviájához (Germuska 2004), majd hasonló szempontok vezettek a nyugati határszakasz periférikus kezeléséhez és a „hátországi” borsodi iparvidék preferálásához a Dunántúllal szemben.

A szocialista korszak területi folyamatainak megítélésekor ki kell térnünk annak kritikajára is, amely a rendszerváltást követỏ évek reformjaiban érhetö legjobban tetten. Így aztán:

- Megszủnt a közigazgatási nómenklatúra diszkriminációja és elméletben egyenjogú önkormányzatok jöttek létre. A megyék hatásköreit csökkentették a források megnyirbálásával, párhuzamos intézményrendszer kiépítésével és a megyei jogú városok különválasztásával.

- Leértékelődött az állami iparpolitika, a hazai nagyipar helyét fokozatosan átvették a közvetlen tőkeberuházásra (foreign direct investment, FDI) épülö zöldmezös beruházások. Ez párhuzamosan folyt a megkésett dezindusztrializáció fölgyorsulásával.

- Megszủnt a szovjet katonai befolyás, az ország minden erejét bevetve közeledett a nyugati biztonságpolitikai, gazdasági rendszerekhez. A korábban kihasználatlan nyugati határvidék az új politikai orientációban egyszerre jelentős helyzeti elönyt kapott, miközben a keleti-déli határ leértékelödött; a magyar politika nem ,a Kelet és a Nyugat közötti hídként”, hanem a Nyugat végváraként határozta meg magát az európai politikai térben.

Ezt a reakciót lényegében hegeli értelemben vett antitézisnek, a szocialista tervezés részleges kritikájának tekinthetjük, amely föltárta a diktatúra büneit, de mivel nem volt képes Magyarország területi fejlödésének új irányt adni, jórészt külső folyamatok alakulására bízta az országot. Ugyanakkor megmaradt, sőt, bizonyos tekintetben fokozódott a föváros központi súlya: a megyei kompetenciákat elnyelve hatalmát, tőkevonzó képességével, a megtelepedö külföldi töke megszürésével gazdaságát tette kvázi egyeduralkodóvá. A szocializmusból fennmaradt központosító, a nemzetállam kizárólagosságában gondolkodó politika meghatározó ereje jól tettenérhetỏ a közgondolkodás evidenciaként elfogadott alaptételében, miszerint az ország egyéb területeinek Budapesttöl kell várniuk a befektetések „odaítélését”, mindezt annak ellenére, hogy a befektetések forrása nem Budapest, hanem NyugatEurópa és az USA (a hazai székhelyủ vállalatok szerepe legjobb esetben is másodlagos). Hasonlóan igaz, hogy bár Magyarország nagyvárosai az államhatárokhoz közel fekszenek, orientációjuk befelé forduló, nem számolnak érdemben a határokon átnyúló kapcsolatok lehetőségeivel. 
Lux Gábor : A magyar fejlesztési politika térszemlélete és a második generációs programozás területi vetületei. Tér és Társadalom 19. évf. 2005/3-4. 81-93. p.

TÉT XIX. évf. 2005 — 3-4

A magyar fejlesztési politika...

85

\section{Magyarország a globális piac müködési rendjében}

Már a rendszerváltás elỏtti években is fokozatos közeledés indult meg a nyugati gazdaság irányába, de a tényleges váltást a szocialista rendszer megszünése jelentette. A rendszerváltás után jelentős dereguláció ment végbe, amely az állam gazdasági szerepvállalásának csökkenésével, egyben a magántőke, elsősorban a külföldi FDI meghatározó jelenlétével új differenciálódást indított meg a magyar térszerkezetben.

A központ erős beavatkozása hiányában a privátszféra értéktermelése juttatott egyes településeket elönyökhöz vagy erősítette meglévő kedvező helyzetüket, míg ennek hiányában stagnálás, visszafejlődés volt tapasztalható. A beruházások elsösorban külföldi forrásokat jelentettek, mert a hazai vállalatok tőkehiánya nem tett lehetővé ilyen nagymértékủ tevékenységbővülést. A külföldi vállalatok megjelenése a kilencvenes évek elején elsősorban a privatizációhoz kötődött, majd a privatizálható állami vagyon elfogyásával a zöldmezős beruházások vették át a fószerepet. Belátható, hogy az első jelenség a korábbi térszerkezeti pozíciók újratermeléséhez vezet, a második pedig a beruházó telephelyválasztási szempontjait tükrözi. Mivel a külföldi vállalatok hozzáadottérték-termelése a hazai tulajdonú vállalatokénak mintegy 250\%-a (OFK 2005), és mivel a beruházott töke mennyisége is jóval magasabb, ez a gazdasági tevékenység differenciál a legerösebben, és a látványos fejlődést mutató régiók is azok, ahol a külföldi vállalatok nagy számban megtelepedtek.

A külföldi vállalatok beruházási döntéseiben a következő szempontok figyelhetók meg:

- Felértékelödött a nyugati piacok megközelíthetősége, így a közlekedési kapcsolatok milyensége és mennyisége. Azaz a nyugat-keleti lejtő eleve érvényesült a távolság miatt, de a dunántúli térségek között is csak azok vonzották a tőkét, amelyek rendelkeztek a megfelelő közlekedési kapcsolatokkal.

- A föváros, és újabban a központi régió vonzza a legtöbb üzleti szolgáltatást, de a tercierizáció mellett az ipari fejlödés is ide koncentrálódik. Csekélyebb, de így is jelentős fejlödés következett be a Budapest-Bécs-tengely mentén, a nyugati határszélen és Heves megyében.

- Az említetteken kívüli térségekbe a főváros közvetítésével jutnak el a gazdasági tevékenységek, és szürőhatás érvényesül, amennyiben az értékesebb, innovatívabb tevékenységeket Budapest megtartja magának (Horváth 1998).

\section{Az uniós integráció, mint a térszemléletet formáló erö}

Magyarország nyugati orientációja és átalakuló gazdasága eleve szemléletváltással járt, de ez mindmáig nem vezetett az állami szinten is megjelenő tudatos térbeli beavatkozáshoz annak ellenére, hogy ennek jelentőségére a szakma már a rendszerváltás idején rámutatott (Faragó-Horváth-Hrubi 1990). Szerepet játszottak ebben a „tervezés” fogalmához tapadó kellemetlen emlékek és a szabadpiac jótékony hatásába vetett, olykor módfelett naivnak bizonyult remények is. 
A cezúrát az EU-integráció támasztotta igények jelentették. A csatlakozási folyamat során hangsúlyossá vált a közösségi normáknak való megfelelés (eurokonformitás), és bár közülük sok nem volt formálisan kötelezö, azért elvárták a teljesítésüket. A szerzö véleménye szerint itt két momentumot tarthatunk - akár általános érvényességgel - kiemelkedő fontosságúnak:

- Ismét legitimitást nyert a tervezés, és ezen beliil a területi tervezés. A közszféra is kezdte belátni, hogy tervezni pedig kell - ha nem is úgy, mint korábban.

- Megindult a területfejlesztés szerepének megvitatása, jelentkezett a közigazgatási, területbeosztási rendszer reformjának igénye (akár egy nagyarányú, bár máig halogatott államreform keretében).

Az addig föleg szakmai, tudományos fórumokon felmerülő kívánalmakat a politika is el- és felismerte, és azokat saját elképzelései szerint beépítette cselekvési rendszerébe, s ennek érdekében törvényeket hozott, illetve intézményeket létesített.

A folyamat nem elsősorban a hatékonyság és a demokratizálás kérdésének megvitatásával kezdődött és zajlott le, hanem az alkalmazkodás logikája mentén, egy olyan helyzetben, ahol az erösebb fél diktálta a csatlakozás ütemét ${ }^{2}$. A hazai döntéshozók azt akarták kitapogatni, hogy mit vár el tỏlünk az EU, és ennek megfelelöen nekik milyen lépéseket kell és lehet megtenniük. Nyilvánvaló volt, hogy a csatlakozás pénz és hatalom kérdése is, és nem mellékes, ki rendelkezik majd fölöttük.

Kérdéses, hogy egyáltalán lehetséges-e az ilyen módon kialakított rendszerrel érdemi változtatásokat végrehajtani - hiszen létrehozása és müködtetése azok kezében van, akik inkább a meglévő struktúrák fenntartásában érdekeltek. Pesszimista elemzök rámutathatnának, hogy a hatalmi viszonyok újratermelése egészen addig folytatódik, amíg valamilyen válság hatására halaszthatatlanná nem válik a reform, vagy (súlyosabb esetben) sor nem kerül a rendszer radikális átalakítására, de ezúttal már külső impulzusok irányításával (v.ö. Faragó 1997). E sorok írója nem látja ilyen sötétnek a képet, de egyúttal rámutat arra is, hogy a potenciális válságokat megelőzni érdemes, túlélni lehet, róluk tudomást nem venni viszont felelőtlenség.

Milyen módon járult hozzá az uniós integráció folyamata a magyar területi politika alakulásához? Erre a kérdésre még korai volna válaszolni, de addig is levonhatunk pár előzetes tanulságot:

- Nem beszélhetünk tudatosan és következetesen alkalmazott területfejlesztési politikáról, amely világos célokat szem elött tartva befolyásolná a térbeli folyamatokat.

- Fennmaradt a beavatkozás ágazati logikája, a területi problémákat párhuzamos horizontális rendszerek próbálják kezelni. A döntéshozatal és a források Miniszterelnöki Hivatalba való átcsoportosítása sem vezetett alapvető változáshoz.

- A létrehozott területi testületek gyengék és képtelenek a területi érdekek artikulációjára - már csak azért is, mert ebben vagy a központi szereplők túlsúlya vagy csekély méretük megakadályozza öket. Téralakító szerepük ma még csak potenciális, a konkrét eredmények jórészt hiányoznak. 
Az előbbieket figyelembe véve nem állíthatjuk, hogy az uniós integráció önmagában jelentősen módosította volna a területi politika irányát. Sokkal hangsúlyosabb a globális gazdaságban elfoglalt helyünk térformáló ereje, aminek szerves része a csatlakozással járó piacnyitás is. Az elöcsatlakozási alapok pénzeszközei sem a területi politikát erősítették, hanem az általános állami fejlesztéspolitika számára biztosítottak többletforrást. Az anyagi folyamatok helyett az integráció pozitív területi hozadéka eddig elsősorban szellemi; a területi szemléletmód megjelenésében és terjedésében fogható meg.

\section{A második generációs programozás területi megalapozása}

\section{Az első Nemzeti Fejlesztési Terv tanulságai}

2004 elején zárult le a Nemzeti Fejlesztési Terv (NFT) kidolgozása, és gyakorlatilag párhuzamosan meg is indult a fölkészülés a következö programozási periódusra. Mindkét esetben az időhiány nyomta és nyomja rá a bélyegét a tervezésre, hiszen amire a régi tagállamoknak hét évük volt, azt nekünk öt év alatt kétszer is meg kell cselekednünk. Ez a kapkodás óhatatlanul növeli a selejt kockázatát, miközben tovább csökken a szakmai-társadalmi kontroll érvényesítésének lehetősége. Mivel a brüsszeli bizottság elégtelennek találta a hazai regionális intézményrendszer fölkészültségét, az NFT kidolgozásában és végrehajtásában egyaránt a központi intézmények játszottak és játszanak föszerepet.

Ahogy arra már többen rámutattak, az NFT a területi megközelítés vereségeként értelmezhető (Faragó 2004b; Márton 2004). Az operatív programok szintjén tisztán horizontális prioritásokkal találkozunk, beleértve ebbe a Regionális Operatív Program prioritásait is. A ROP neve ellenére nem az egyes régiók, hanem „a" régiók programja, illetve a bennfoglalt prioritások ismeretében az sem. A versenyképesség fokozására irányuló intézkedések a már eleve érvényesülỏ területi differenciálódást erősítik többletforrások mobilizálásával: a források megszerzésében nagyobb hatékonyságot fölmutatni képes, fejlettebb régiók felé áramolhatnak a pénzek. A III. Kohéziós Jelentés is említi az ellentmondást a regionális és nemzeti konvergencia között - a szegényebb tagállamok uniós átlaghoz történő felzárkózása során gyakran nöttek a belső, regionális különbségek. Ezt támasztják alá más új EU-tagok és tagjelölt országok tapasztalatai is; országon belüli konvergencia csak Bulgáriában, Lengyelországban és Romániában következett be (Egger-Huber-Pfaffermayr 2005).

\section{A második generációs programozást megalapozó dokumentumok térszemlélete}

A második generációs programozás rendszere három pillérre épül, amit negyedikként a Brüsszel hatáskörébe tartozó nagyprojektek egészítenek ki. Az elsö ezek közül a fejlesztési tevékenység általános kereteit kijelölő Országos Fejlesztéspolitikai Koncepció (OFK), a második a II. Nemzeti Fejlesztési Terv (újabb nevén Nemzeti Stratégiai Referenciakeret), a harmadik pedig az új Országos Területpolitikai 
Koncepció (OTK) (Márton 2004). A tervdokumentumok közül az első kettö szorosan összefügg, míg a harmadik a területi dimenzió fokozott bevonásával némileg kirí a csoportból. Mindhárom dokumentum szakmai anyag, végleges formájukat csak a politikai szürőn átjutva nyerik el. Az OFK és a II. NFT-t megalapozó munkaanyag érdeklödésének középpontjában a versenyképesség és a méltányosság kettős kérdése áll. Az általános fejlesztési irány a versenyképesség növelése marad, ami mellett a méltányosság másodlagos szerepet tölt be, elérését is elsösorban a mobilitás, a versenyképesség növekedésén keresztül tartják elérhetönek. A területi folyamatokat növekedési pólusok fejlesztésével kívánják befolyásolni, kiemelve köziulük Budapestet. Budapestet a koncepciókban rendre nemzetközi kontextusban emlegetik, egyrészt mint Magyarország és az EU közötti közvetítő láncszemet, másrészt mint hidat Délkelet-Európa, a Balkán felé.

A dokumentumok tervezési szemlélete megítélésünk szerint továbbra is a centralizált állam nézőpontjából indul ki; a területi kủlönbségek mérséklését az államszervezet múködési hatékonyságának javításával, illetve a centrum és a perifériák erösebb összekötésével kívánja elérni. A decentralizáció igénye nincs jelen következetesen, kevés szó esik a regionális önkormányzatiságról, és ez az elképzelés sokkal kevésbé hangsúlyos, mint a tárcaközi koordináció erősítése, az állami beavatkozások konzisztenciájának fokozása. Így a fejlesztéspolitika horizontális eszközökkel történő integrálása valósul meg, ami csakugyan hatékonyságerősítỏ hatású. Ellenben ez az unitárius állam hatékonysága és nem a decentralizált államé - vagy a status quo megörzését, vagy a további hatalmi koncentráció ügyét szolgálja, és a testületközi torzsalkodás feudális állapotait a kancellária felvilágosult (?) abszolutizmusára cseréli.

Az elöbbi két dokumentumtól eltérően az új OTK valódi területfejlesztési dokumentum. Térszemléletének alapköve az EU döntéshozó szerveiben is egyre inkább orákulumként tisztelt ESDP policentrikus területi modellje. A fejlödés motorjait jelentő városok és az őket körülvevő terek integrációja révén hozható létre a tartós növekedés bázisa egy hierarchikus, de egyúttal a szubszidiaritás elvének is megfelelő térfelosztási rendszer keretében ${ }^{3}$. Az OTK ennek a magyar városhierarchia elemeit felelteti meg. Budapest mellett kiemelt funkciót szán a regionális centrumoknak, amelyek kőzvetítőkként saját régióik fejlödési bázisaivá válnak. A gazdasági növekedés a hierarchikus pontokat összekötő közlekedési, kommunikációs és a tudásáramlást elősegítỏ hálózatokon keresztül terjed szét, alkalmazkodva a térségi adottságokhoz. Az európai térben az egész ország kapocsszerepét hangsúlyozza, amely így a nyugati területekkel fenntartott intenzív kapcsolatok kihasználásával a Kárpát-medence és a délkelet-európai terek integrátorává lép elö.

Területfejlesztési, tervezési szemszögből az OTK-t tekinthetjük a második generációs programozás legvilágosabb koncepcióval rendelkező elemének. Szemlélete adaptív, a külső elképzelések hazai átültetésének tekinthetö. Egyedüliként a tervdokumentumok közül az OTK felismeri az eltérỏ regionális sajátosságok szerepét, és fejlödési alternatívákat fogalmaz meg ezek kihasználására. Sajnos a koncepció kívülállása, a fejlesztési politika foóramától való távolsága és formális szerepe miatt várhatóan csak kiegészító szerepet kap majd a 2007-2013-as programozási periódusban. 
Lux Gábor : A magyar fejlesztési politika térszemlélete és a második generációs programozás területi vetületei. Tér és Társadalom 19. évf. 2005/3-4. 81-93. p.

\section{Válaszlehetőségek a térszervezés kihívásaira}

A tanulmány lezárásában arra keresünk választ, hogy a területi tervezés korlátozott mozgástere miként tölthetö ki a kiegyensúlyozottabb területi fejlődést elömozdító intézkedésekkel. Be kell látnunk, hogy Magyarország fejlődése továbbra is a szocializmus fokozatosan halványuló örökségén építkezve, a globális piac rendszerében és immár az Európai Unión belül zajlik majd le. Azaz vannak olyan tényezők, amelyekhez alkalmazkodnunk kell, rájuk csak minimális befolyást gyakorolhatunk. Jelesül:

- A gazdasági növekedés forrása a külföldi FDI marad, és ezen semmilyen állami intervenció nem lesz képes változtatni, mivel eszközei erre elégtelenek: legjobb esetben a hatások területi diszperziójának fokozása képzelhető el. Nem változnak a transznacionális vállalatok telephelyválasztási szempontjai; föként az elérhetőség és a nyugati piacok megközelíthetősége fog latba esni, illetve eltérő típusú beruházások valósulnak meg a nagyvárosokban és rajtuk kívüil ${ }^{4} . \mathrm{Az}$ FDI beáramlásával folytatódik a területi differenciálódás is. Ennek a kérdésnek a fejlesztéspolitika még mindig nem szentel kellő figyelmet, és helyette az egyre zsugorodó állami befolyás elosztási lehetőségeit latolgatja.

- Az Európai Unió prioritása a megújított lisszaboni stratégia megvalósítása és a gazdasági növekedés fokozása lesz, hozzá képest minden más célkitűzés háttérbe szorul. A változások irányát a Kohéziós politika a növekedés és a foglalkoztatás érdekében c. dokumentum fogalmazza meg. A növekedési szemléletben a regionális különbségek kezelése és a konvergencia is a versenyképességet növelö intézkedések keretében valósul meg. A növekedési pólusok kiemelt figyelmet kapnak a tervezésben; az elmaradott területek fölemelkedését a központok és a nagy európai hálózatok elérhetőségének fokozásával kívánják megoldani. Ez érvényes mind összeurópai szinten (Pentagon vs. perifériák), mind az egyes tagállamokon belül (nagyvárosok vs. háttérterületek).

Tény, hogy a közösségi és a hazai politika egyaránt növekedés- és versenyképességpárti. Az elsőn nem lehet, a másodikon (ezt figyelembe véve) nem érdemes változtatni. A növekedést elsödlegesen gerjesztő FDI ott és olyan mértékben járul hozzá a fejlödéshez, ahol és amennyire a lokális feltételek ezt elösegítik. A nyugat-keleti lejtỏ nem szüntethetô meg, de meredeksége mérsékelhető a nyugati piacok elérhetóségének javításával. Kívánatos a terjedés sebességének és szélességének fokozása, hogy lehetőleg minél több terület részesüljön a befektetések kedvező hatásaiból. A növekedés eredményeinek diffúziójában az EU-politikákkal is összhangban álló policentrikus városrendszerre alapozó fejlesztés célravezetö, amelynek az OTK jó alapját adja.

A sugaras közlekedési szerkezet fövárosi koncentrációt konzerváló és a szürőszerepet fenntartó struktúrája csak fokozatosan és részlegesen oldható. Az EU erős növekedést mutató északolasz-alpi nagyrégiója felé kiépített, az ország déli részén (a Nagykanizsa-Pécs-Szeged-Debrecen vonalon) áthúzódó nagy áteresztőképességủ 
közlekedési folyosó egy második csatornát adna hazánknak. Létrehozásához azonban nemzeti eszközök szükségesek, mert a transzeurópai hálózatok (TEN) közlekedésfejlesztési elképzeléseiben nem kapott hangsúlyos szerepet. A megközelíthetőség mellett kulcsszerepet kell kapjon a területi befogadóképesség, a jól képzett és kedvező árú munkaerỏbázis, az üzleti szolgáltatások sokfélesége és színvonala is, mivel ezek a tényezök fokozzák a külföldi töke beágyazottságát és csökkentik menekülésének veszélyét.

Megfontolandó, hogy a területfejlesztésben milyen feladatok mely közigazgatási szinteken valósuljanak meg. A még üres régió, a már (majdnem) üres megye és a kistérség együtt áttekinthetetlen és megosztott, nem alkalmas a hatalom hatékony befogadására. Valószínủnek tủnik, hogy valamelyiket de facto ki kellene vonni a területi tervezésből. Valószínủleg két, egymástól távolabb eső méretủ szint kialakítása lenne célszerü: egyik ezek közül a régió, a másik vagy a megye, vagy a kistérség ${ }^{5}$.

A regionális szint kialakítása Magyarországon a regionális hagyományok hiánya ellenére szükségesnek tủnik. A status quo fenntartásában érdekelt elképzeléseket leszámítva a fejlesztési koncepciók a régióközpontok megerösödésével számolnak; ez az irány egyben az uniós területi politika érdeklődésében is elötérbe került, ergo támogatható. A policentrikus városfejlödés megfelelő intézményrendszer birtokában a regionalizáció motorja lehet, fokozatosan kiépítve térségi kapcsolatrendszerét és gazdasági terét. Egyetérthetünk tehát abban Faragó Lászlóval, hogy ha lesz tartalmában erős regionalizáció, az elsősorban politikai lesz, alapját és folyamatát pedig az államreform müködési hatékonyságra összpontosító szempontjai teremtik meg (Faragó 2004).

A régiók kialakítása azonban nem ỏnmagában való cél, tehát nem mindegy, hogy tényleges decentralizációval jár-e. Kérdéses, hogy létezik-e a régiók fölött demokratikus kontroll: véleményünk szerint ma még ilyen nincs, a civil szféra nincs jelen regionális szinten; mi több, nem is ,ismeri” a régiókat. A régióépítés nem vezet automatikus demokratizálódáshoz, sikertelen megvalósulása esetén a meglévő demokráciadeficit újraelosztásának eszközévé válhat. Nem eldöntött, kik hivatottak a régiók vezetésére: a jelenlegi gyenge testületekben a szakmai racionalitás háttérbe szorult, és a központi (párt)politika „lenyelte” az irányítást, ezzel megkérdőjelezve az egész folyamat értelmét. Hasonlóan tisztázatlan a civil szféra, a gazdasági szereplők és az önkormányzatok részvétele a kialakuló rendszerben. A központi szabályozás feladata, hogy - saját hosszútávú érdekében is - megakadályozza a folyamat félresiklását, a decentralizáció központi vagy nagyvárosok általi megszállását.

Így a decentralizáció három fö forgatókönyvéröl beszélhetünk:

- Sor kerül az érdemi decentralizációra, és bekövetkezik az erôs területi integráció; a városok központi szerepköre az elérhetőség javulásával a városkörnyéki területekre is kedvezö hatást fejt ki; a helyi gazdaságok erős térkapcsolatokkal integrálódnak az országos és európai hálózatokba. Ezt a regionalizáció kedvező forgatókönyvének tekinthetjük (,régiók városokkal”). 
- Megvalósul a decentralizáció, de a növekedés először csak a városokban következik be. A területi integráció elhúzódik, az irányító szerep egyértelműen a régióközpontoké marad. Ez a forgatókönyv középutat képvisel (,városok régiókkal").

- A decentralizáció gyenge marad, esetleg az uniós költségvetés radikális megkurtításával nem valósulnak meg a várt fejlesztési programok. A regionális tartalom pár városra koncentrálódik, amelyek erős függésben maradnak a fővárossal szemben. Ez a regionalizáció kedvezőtlen forgatókönyve (,régiók városokból”).

A valóságban természetesen nem föltétlenül egyik vagy másik forgatókönyv következik be, hanem ezek területileg és időben differenciált megvalósulása várható, pl. egyes területek erősebb, mások gyengébb integrációja; a nagyváros-vidék kapcsolatok fokozatos, esetleg helytöl függően késlekedö kiépülése. A szerző véleménye szerint a szélesebb bázisú, kiegyensúlyozottabb eloszlású területi növekedés nem zérusösszegủ játszma, a vidék fejlődése már középtávon is erỏsítené a központ pozícióit. A reform azért is időszerủ, mert uniós csatlakozásunk után nem a vidék Budapest riválisa, hanem a többi új és régi tagállam az egész országé. A belső hatalmi differenciák mindenkit sebezhetővé tesznek, miközben az állam ,parlagon hagyott" területei tényleges vagy alternatív költségek (opportunity cost) formájában károsítják meg a közjót. A területfejlesztési politika feladata, hogy föltárja a hatékony decentralizációt elősegítő, politikailag is vállalható döntési lehetőségeket, és ezeket úgy dolgozza ki, hogy azok ne mondjanak ellent az Európai Unió folyamatosan átalakuló területfejlesztési elveinek és a globalizálódó világ kihívásainak.

\section{Jegyzetek}

${ }^{1}$ Itt gyakran már korábban is voltak ipartelepek, de egyetérthetünk abban a hivatalos ideológiával, hogy a szocialista beavatkozás hatására hatalmas fejlödésen mentek keresztül (Markos 1962).

${ }^{2}$ A folyamathoz a nyugati oldal egyfajta elöítéletes távolságtartása is társult, míg a csatlakozó országok vélt vagy valós múltbéli sérelmeik, kirekesztettséguk kompenzációjának igényével léptek föl vele szemben. A hatalmi aszimmetria a csatlakozási folyamat elhúzódásában és az új tagállamokkal szembeni diszkriminációban jelent meg (Domanski 2004; Kuus 2004).

${ }^{3}$ Faragó László fölhívja a figyelmet arra, hogy Magyarországon a nagyvárosokat megerősítỏ fejlesztés (,'koncentrált decentralizáció”) alapozhatja meg a későbbi magasabb fokú decentralizációt (Faragó 2005).

4 A transznacionális vállalatok a nagyvárosokba koncentrálódnak és itt tökeintenzívebb fejlesztéseket valósítanak meg; a nem-nagyvárosi területek inkább a közép- és kisméretủ beruházók munkaintenzív tevékenységét fogadják be, ami új területi munkamegosztás kialakulásával jár (Domanski 2003).

${ }^{5}$ Egy megerösített, városhálózati-városkörnyéki alapokra helyezett kistérségi szint megfelelö kompromisszum lenne, egyben részlegesen „településpótló" szerepet vállalhatna a dezintegrált települési önkormányzati rendszerben, amelynek konszolidálása politikai okokból ma nem reális lehetőség. A kistérségi központok nem csak koordinálnák, hanem ellátnák a magasabbrendủ települési funkciókat, miközben az egyes községek szintjén megmaradna az alapszintủ ellátás. 


\section{Irodalom}

Barta Gy. (2002) A magyar ipar terïleti folyamatai 1945-2000. Dialóg Campus Kiadó, Budapest-Pécs.

Beluszky P. (2000) Adalékok a városhálózat 1990 utáni átalakulásához. - Horváth Gy.-Rechnitzer J. (szerk.) Magyarország területi szerkezete és folyamatai az ezredfordulón. MTA Regionális Kutatások Központja, Pécs. 115-129. o.

Beluszky P. (2002) Hittétel vagy a gazdasági földrajz alapkategóriája - avagy léteznek-e komplex gazdasági körzetek? - Beluszky P. (szerk.) Vég kiárusítás II. Társadalomföldrajzi tanulmányok. MTA Regionális Kutatások Központja, Pécs. 7-21. o.

Beluszky P. (2003) Magyarország telepillésfóldrajza. Általános rész. Dialóg Campus Kiadó, BudapestPécs.

Cohesion Policy in Support of Growth and Jobs. Community Strategic Guidelines, 2007-2013. (2005) European Commission, Brussels.

Domanski, B. (2003) Industrial change and foreign direct investment in the postsocialist economy. European Urban and Regional Studies. 10. 2. 99-118. o.

Domanski, B. (2004) West and east in 'New Europe': the pitfalls of paternalism and a claimant attitude. - European Urban and Regional Studies, 11. 4. 377-381. o.

Egger, P.-Huber, P.-Pfaffermayr, M. (2005) A note on export openness and regional wage disparity in Central and Eastern Europe. - The Annals of Regional Science. 39. 1. 63-72. o.

European Spatial Development Perspective. (1999) European Commission, Brussels.

Faragó L.-Horváth Gy.-Hrubi L. (1990) Szerkezetátalakitás és regionális politika. Ts-2/2 Program Iroda, Budapest.

Faragó L. (1997) Tervezéselméleti alapvetések, - Tér és Társadalom. 3. 1-15. o.

Faragó L. (2000) A (teriilet)fejlesztés irányítási algoritmusa a programozás, - Horváth Gy.-Rechnitzer J. (szerk.) Magyarország teruileti szerkezete és folyamatai az ezredfordulón. MTA Regionális Kutatások Központja, Pécs. 527-541. o.

Faragó L. (2004a) A regionalizmus hajtóerői Magyarországon. - Tér és Társadalom. 3. 1-24. o.

Faragó L. (2004b) Javaslatok az új Nemzeti Fejlesztési Terv regionális megalapozásához. - EUtanulmányok IV. Nemzeti Fejlesztési Hivatal, Budapest.

Faragó L. (2005) A jövőalkotás társadalomtechnikája. Dialóg Campus Kiadó, Budapest-Pécs.

Germuska P. (2004) Indusztria bũvöletében: fejlesztéspolitika és a szocialista városok. 1956-os Intézet, Budapest.

Hajdú Z. (2001) Magyarország közigazgatási földrajza. Dialóg Campus Kiadó, Budapest-Pécs.

Horváth Gy. (1989) A regionális gazdaságszervezés fejlödése és intézményei. Akadémiai Kiadó, Budapest.

Horváth Gy. (1998) Európai regionális politika. Dialóg Campus Kiadó, Budapest-Pécs.

Kuus, M. (2004) Europe's eastern expansion and the reinscription of otherness in East-Central Europe. Progress in Human Geography. 4. 472-489. o.

Markos Gy. (1962) Magyarország gazdasági földrajza. Közgazdasági és Jogi Könyvkiadó, Budapest.

Márton Gy. (2004) Az Elsö Magyar Nemzeti Fejlesztési Terv tervezési folyamatának tapasztalatai regionális szemszögböl. - Falu, város, régió. 9. 32-45. o.

Országos Fejlesztéspolitikai Koncepció. Munkaanyag (2005. április 4.) (2005)

Országos Terïletpolitikai Koncepció. Munkaverzió (2005. április 5.) (2005) Magyar Terùlet- és Regionális Fejlesztési Hivatal, Budapest.

Új partnerség a kohézió érdekében [llI. Kohéziós Jelentés]. (2004) Európai Bizottság, Brüsszel.

Winiecki, J. (1986) Az ipar túlméretezettsége a kelet-európai szocialista országokban: tények, okok, következmények. - Közgazdasági Szemle. 5. 579-592. o. 
Lux Gábor : A magyar fejlesztési politika térszemlélete és a második generációs programozás területi vetületei. Tér és Társadalom 19. évf. 2005/3-4. 81-93. p.

TÉT XIX. évf. 2005 - 3-4

A magyar fejlesztési politika...

93

\title{
VIEWS ON SPACE IN HUNGARIAN DEVELOPMENT POLICY AND THE SPATIAL ASPECTS OF SECOND GENERATIONAL PROGRAMMING
}

\author{
GÁBOR LUX
}

This paper examines how Hungarian spatial development policy has evolved with respect to its views on space, and how this can be reconciled with the changes in economic processes. Hungarian spatial development policy stems from the partial critique of Socialist spatial planning, which put into practice discriminatory policies favouring towns and industrial development with a special emphasis on militarization. Post-transformation is still characterised by an excess of recentralization, which is evident from current development documents.

In order for the new second generational planning to be successful, we must take into account EU reforms and the defining influence of the global economy. Territorial reforms must take place, but they must be undertaken with an eye for effectiveness and democratic accountability. 